\title{
1. Introduction: rewriting decisions from a perspective of human rights integration
}

\section{Eva Brems}

As a political and ethical project, human rights are one, indivisible and universal. As law however, they are fragmented: found in a multitude of different legal sources, several of which have their own monitoring bodies, each with their own dynamic.

Some scholars have proposed a 'World Court of Human Rights' as a means to realize the fundamental unity of the human rights project in international human rights law. ${ }^{1}$ The present project however, intends to show that even within the current fragmented landscape of international human rights law, it is possible to 'integrate' human rights to a significantly higher degree than is generally the case.

The book introduces concrete and innovative proposals for a holistic ('integrated') approach to supranational human rights justice through a hands-on legal exercise: the rewriting of decisions of supranational human rights monitoring bodies. The scholars who participated in this project have thus redrafted crucial passages of landmark human rights judgments and decisions. In addition to the rewriting exercise, authors have outlined the methodology and/or theoretical framework that guided their approaches and explained how and why, in their opinion, human rights monitoring bodies may adopt an integrated approach to human rights law.

As a human rights integration project, its purpose is to rewrite decisions and judgments of specific supranational human rights monitoring bodies in such a way that they look beyond the confines of the specific instrument(s) with which that body works as well as beyond the limits

1 M Scheinin, Towards a World Court of Human Rights, Report 2009, http://www.eui.eu/Documents/DepartmentsCentres/Law/Professors/Scheinin/ WorldCourtReport30April2009.pdf; Julia Kozma, Manfred Nowak and Martin Scheinin, A World Court of Human Rights - Consolidated Statute and Commentary (Wissenschaftlicher Verlag 2010). 
of the level of jurisdiction at which it is established. Scholars have been invited to rewrite these decisions 'as if human rights law were really one', borrowing or taking inspiration from developments and interpretations throughout the whole multi-layered human rights protection system.

As a rewriting project, its purpose is to show how theoretical and conceptual approaches from scholarship can be translated into judicial practice. Some of the participating scholars hold or have held positions within supranational human rights monitoring bodies and have ample experience in crossing the bridge between academia and the practice of human rights monitoring. ${ }^{2}$ Yet for most contributors, this project has been a deliberate step outside their academic comfort zone.

This chapter first outlines the framework of this volume, that is, the concept of human rights integration (1) and the methodology of rewriting (2). It then introduces the 15 rewritten opinions (3) before analysing the contributors' rewriting in terms of 'what', 'how' and 'why' (4).

\section{HUMAN RIGHTS INTEGRATION}

The book's theoretical angle is that of an integrated, holistic perspective to human rights law. ${ }^{3}$

In public opinion, 'human rights' are often portrayed as a clear and homogenous concept. Yet those who work in the field of human rights know that reality is very different. A seemingly simple question such as 'show me the list of all human rights' or 'draft me a list of all human rights' is certain to generate as many different lists as there are human rights experts. Indeed, there is no such thing as a single human rights catalogue. Instead, human rights are found in a multitude of highly diverse sources. These can be differentiated in several cross-cutting ways. ${ }^{4}$ In the first place,

2 Martin Scheinin was a member of the United Nations Human Rights Committee from 1997 to 2004. In 2005 he was appointed as the first United Nations Special Rapporteur on human rights and counter-terrorism, a position he held until July 2011. Gerald Neuman was a member of the Human Rights Committee from 2011 to 2014. Rhona Smith has been the UN Special Rapporteur on Cambodia since March 2015.

3 Several contributors participate in the research project 'The Global Challenge of Human Rights Integration: Towards a Users' Perspective', sponsored by the Belgian Science Policy Office (BELSPO), 2012-2017: see www.hrintegration.be (accessed 6 March 2017).

4 See Eva Brems, 'Should pluriform human rights become one? Exploring the benefits of human rights integration' 20144 European Journal of Human Rights $447-70$. 
human rights texts differ with respect to the governance level at which they operate. Relevant government levels range from the (sub)national - as states include rights catalogues in constitutions or separate charters ${ }^{5}$ - over the (sub)regional - for example, European Union, Council of Europe, Organisation of American States (OAS), African Union, Association of Southeast Asian Nations - to the global - United Nations and specialized agencies such as the International Labour Organisation. In addition, a typology of human rights texts can be made on the basis of their scope ratione materiae. The format of the Universal Declaration of Human Rights (UDHR), as well as that of domestic (constitutional or other) rights charters is that of a single comprehensive rights catalogue. The same format is found at the regional level in the African Charter on Human and Peoples' Rights and the European Union Charter of Fundamental Rights. Yet in the Council of Europe system as well as the Inter-American system, the basic texts are categorical texts, restricted to civil and political rights, ${ }^{6}$ with a separate text on economic, social and cultural rights. ${ }^{7}$ Similarly at the United Nations level, the conversion of the rights in the UDHR - a UN General Assembly resolution - into treaty law resulted in two categorical treaties, the International Covenant on Civil and Political Rights (ICCPR), and the International Covenant on Economic, Social and Cultural Rights (ICESCR). To these categorical texts have been added a number of single-issue texts, each addressing a specific type of human rights violation,

5 The author is well aware of the fact that some legal traditions (in particular in the United States) conceive of international human rights and domestic civil rights as separate bodies and disciplines. However, in many parts of the world, in particular in states with a monist system, international human rights provisions are invoked before domestic courts alongside constitutional provisions. This results in a scholarly position that views the study of constitutional fundamental rights and that of international fundamental rights as part of the same field of study and uses the term 'human rights' for both. Moreover, this position is justified historically, as national bills of rights have inspired both the format and content of the Universal Declaration of Human Rights and subsequent human rights treaties, which in turn have inspired constitution makers to mirror or add to international provisions in domestic rights catalogues.

6 In the Council of Europe (CoE) this is the (European) Convention for the Protection of Human Rights and Fundamental Freedoms (1950), and in the Organization of American States (OAS) the American Convention on Human Rights (1969).

7 In the Council of Europe this is the European Social Charter (1961), Revised European Social Charter (1996); in the OAS the Additional Protocol to the American Convention on Human Rights in the Area of Economic, Social and Cultural Rights ('Protocol of San Salvador'), 1990. 
such as torture,${ }^{8}$ enforced disappearance, ${ }^{9}$ racial discrimination ${ }^{10}$ or the death penalty. ${ }^{11}$ Some of these texts define a human rights violation that was not, as such, recognized in earlier comprehensive or categorical texts within the same system (for example, 'enforced disappearance'), which may in some cases imply a different legal position (for instance, the protocols on the abolition of the death penalty, allowed as an exception to the right to life in the general texts). All of these single-issue texts define new obligations for states that were not necessarily read into any provision in prior general texts addressing the same right. Moreover, human rights instruments can also be differentiated on the basis of their scope ratione personae. Many instruments are universal, applying to all human beings within the jurisdiction of the states parties. Yet some instruments develop rights for a specific target group, for example, women, ${ }^{12}$ children, ${ }^{13}$ persons with disabilities, ${ }^{14}$ or

8 United Nations (UN), 'Convention Against Torture and Other Cruel, Inhuman or Degrading Treatment or Punishment (CAT)' (1984); CoE, 'European Convention for the Prevention of Torture and Inhuman or Degrading Treatment or Punishment' (1987); OAS, 'Inter-American Convention to Prevent and Punish Torture' (1985).

9 UN, 'International Convention for the Protection of All Persons from Enforced Disappearance (CED)' (2006); OAS, 'Inter-American Convention on Forced Disappearance of Persons' (1994).

10 United Nations, 'International Convention on the Elimination of All Forms of Racial Discrimination (CERD)' (1965); Organization of American States, 'Inter-American Convention Against Racism, Racial Discrimination and Related Forms of Intolerance' (2013); see also more broadly on discrimination: Inter-American Convention Against All Forms of Discrimination and Intolerance (2013).

11 UN General Assembly (UNGA), 'Second Optional Protocol to the International Covenant on Civil and Political Rights Aiming at the Abolition of the Death Penalty' (1989); CoE, 'Protocol No 6 to the Convention for the Protection of Human Rights and Fundamental Freedoms concerning the Abolition of the Death Penalty' (1983); CoE, 'Protocol No 13 to the Convention for the Protection of Human Rights and Fundamental Freedoms, concerning the Abolition of the Death Penalty in All Circumstances' (2002); OAS, 'Protocol to the American Convention on Human Rights to Abolish the Death Penalty' (1990).

12 UNGA, 'Convention on the Elimination of All Forms of Discrimination Against Women (CEDAW)' (1979); OAS, 'Inter-American Convention on the Granting of Civil Rights to Women' (1948); OAS, 'Inter-American Convention on the Granting of Political Rights to Women' (1948); ACHPR, 'Protocol to the African Charter on Human and Peoples' Rights (ACHPR) on the Rights of Women in Africa' (2003).

13 UNGA, 'Convention on the Rights of the Child (CRC)' (1989); ACHPR, 'African Charter on the Rights and Welfare of the Child' (1990).

14 UNGA, 'Convention on the Rights of Persons with Disabilities (CRPD)' (2006). 
members of minority or indigenous groups. ${ }^{15}$ As a rule, the latter types of instrument define detailed state obligations that were not necessarily read into prior universal instruments. It is to be noted that a small number of human rights instruments combine a personal focus with a substantive focus, addressing for example violence against women, ${ }^{16}$ or exploitation of children. ${ }^{17}$ Yet another way of distinguishing between human rights texts concerns the legal force of the instrument. Numerous human rights norms - constitutions, treaties, customary international law - are binding, yet human rights have also been included in formally non-binding soft law for example, declarations and resolutions. In international law, and in particular in international human rights law, the distinction between hard and soft law is less fundamental than in domestic law. It has been recognized by the International Court of Justice that non-binding international rules may nevertheless have a 'normative value'. ${ }^{18}$ Moreover, international human rights arguably rely more on their political and moral force than on their legal force. ${ }^{19}$ Yet the difference continues to matter for those who are framing human rights arguments, as arguments from soft law will be most effective when they are not put forward as self-sufficient arguments, but rather as interpretative lenses for the reading of binding provisions, or as arguments of authority to decide between competing interpretations of hard law. Finally, there is a great variety among the monitoring mechanisms that accompany binding human rights instruments: these range from judicial

15 UNGA, 'United Nations Declaration on the Rights of Indigenous Peoples' (2007); UNGA, 'Declaration on the Rights of Persons Belonging to National or Ethnic, Religious or Linguistic Minorities' (1992); International Labour Organisation (ILO), 'Indigenous and Tribal Peoples Convention' (1989); CoE, 'Framework Convention for the Protection of National Minorities' (1992).

16 UNGA, 'Declaration on the Elimination of Violence Against Women' (1993); OAS, 'Inter-American Convention on the Prevention, Punishment and Eradication of Violence Against Women' ('Convention of Belém do Pará') (1994), $\mathrm{CoE}$, 'Convention on Preventing and Combating Violence against Women and Domestic Violence' (2011).

17 ILO, 'Worst Forms of Child Labour Convention' (1999). See also UNGA, 'Optional Protocol to the Convention on the Rights of the Child on the Sale of Children, Child Prostitution and Child Pornography' (2000); UNGA, 'Optional Protocol to the Convention on the Rights of the Child on the Involvement of Children in Armed Conflict' (2000).

18 International Court of Justice (ICJ), Legality of the Threat or Use of Nuclear Weapons, Advisory Opinion, 8 July 1996, ICJ Reports (1996) 226, 254, para 70.

19 Even binding judgments of supranational human rights courts ultimately rely on political pressure for their execution. See also Courtney Hillebrecht, Domestic Politics and International Human Rights Tribunals: The Problem of Compliance (Cambridge University Press 2013). 
control - the European Court of Human Rights, the Inter-American Court of Human Rights, the African Court of Human and Peoples' Rights - over quasi-judicial control - complaints examined by expert committees ${ }^{20}-$ to other forms of expert control and political control - reporting procedures ${ }^{21}$ Special Rapporteurs and so on. Needless to say, each of these bodies has its idiosyncratic ways of reasoning - a method of interpretation that is favoured by one body may be rejected by another. ${ }^{22}$ Also, the different types of output of these bodies - judgments, views, reports, general comments, concluding observations and so on - have their own format and style that require some familiarity for optimal understanding. UN treaty monitoring bodies for example will rarely use the term 'violation' in concluding observations on state reports - instead expressing 'grave concern' - whereas in their views on individual complaints, their reasoning is focused on finding (or not) a human rights violation.

While each of these sources is internally coherent and each monitoring body has developed its own broadly consistent case law using its own

20 These are in particular the procedures before the Inter-American Commission on Human Rights and the African Commission on Human and Peoples' Rights, as well as the individual complaint procedures that exist before most United Nations human rights treaty monitoring bodies: the Human Rights Committee (on the basis of the First Additional Protocol to the ICCPR), the Committee on the Elimination of Discrimination Against Women (on the basis of the Optional Protocol to the CEDAW), the Committee Against Torture (under article 22 CAT), the Committee on the Elimination of Racial Discrimination (under article 14 CERD), the Committee on the Rights of Persons with Disabilities (based on the Optional Protocol to the CRPD), the Committee on Enforced Disappearances (under article $31 \mathrm{CED}$ ), the Committee on Economic, Social and Cultural Rights (based on the Optional Protocol to the ICESCR), and the Committee on the Rights of the Child (under the Third Optional Protocol to the CRC). Moreover, an individual complaint procedure is foreseen before the Committee on Migrant Workers but this has not yet entered into force. In addition, the collective complaints procedure before the European Committee of Social Rights (Additional Protocol of 1995 to the European Social Charter providing for a system of collective complaints) is noteworthy. This procedure is open to NGOs, as well as to organizations of employers or employees.

21 Self-reporting followed by discussion of the report by an expert body may be considered the standard international human rights monitoring procedure on account of its wide use at the global as well as regional levels (Rhona K M Smith, Textbook on International Human Rights (Oxford University Press 2012) 154).

22 An eloquent example is the 'consensus criterion', frequently used by the European Court of Human Rights (K Dzehtsiarou, 'European consensus and the evolutive interpretation of the European Convention on Human Rights' (2011) 12 German Law Journal 1730), yet explicitly rejected by the Inter-American Court of Human Rights (IACHR, Atala Riffo and daughters $v$ Chile, 24 February 2012, para 92). 
interpretation tools, the picture as a whole is rather complex. It is a reality of legal pluralism, ${ }^{23}$ which can be experienced as a mega-mall in which rights holders can go 'forum shopping', thus benefiting from the diversity of norms, yet also as a labyrinth in which they - and their rights - may get lost.

From an academic perspective, it is perfectly justifiable to focus on a single mechanism. However, for the 'users' of international human rights law, that is, those who work with international human rights law in practice, this is not feasible. All states have ratified several human rights treaties that apply simultaneously. For a state that seeks to avoid violating human rights, or to optimize human rights protection, it is therefore necessary to look at its human rights commitment as a whole. Any individual who experiences injustice can claim human rights from several international sources, in addition to a number of sources of domestic law. Yet when a single instance of injustice touches upon several human rights, it is likely that the individual who seeks justice before a supranational human rights monitoring body, will be able to invoke only some rights, the others remaining dead letter.

Confronted with a multitude of sources of human rights law, scholars and practitioners alike have been struggling with the question of how to fit it all together for optimal human rights protection. The concept of indivisibility is mobilized to discuss the interrelation of economic and social rights with civil and political rights. ${ }^{24}$ And to address the fact that individuals may be at the crossroads of several 'special regimes' of human rights law, the lens of intersectionality has been suggested. ${ }^{25}$ In this volume, indivisibility and intersectionality are but two manifestations among many of a much broader project, which is that of treating human rights law as an integrated whole. The rewritten opinions show very concretely how this can be done.

\section{METHODOLOGY}

\subsection{Human Rights Integration in International Human Rights Law}

International law offers only limited guidance to the topic of human rights integration. Article 31(3)(c) of the Vienna Convention on the

\footnotetext{
23 P S Berman, 'Global Legal Pluralism' (2007) 80 Southern California Law Review 1155.

24 For example Valeska David, p 155.

25 For example Eva Brems, p 248.
} 
Law of Treaties states as a general rule of treaty interpretation that: 'there shall be taken into account, together with the context: ... (c) any relevant rules of international law applicable in the relations between the parties.' Koskenniemi has named this 'the principle of systemic integration', and described it as a process 'whereby international obligations are interpreted by reference to their normative environment' ${ }^{2}{ }^{26}$ In a report for the International Law Commission (ILC), he has formulated the rule of systemic integration as follows: 'This means that although a tribunal may only have jurisdiction in regard to a particular instrument, it must always interpret and apply that instrument in its relationship to its normative environment - that is to say "other" international law. ${ }^{27}$ This 'other international law' includes conventions concluded among the same parties, or even - according to the ILC's preferred interpretation - those concluded by the party/parties in the dispute (and not necessarily all other parties to the main treaty). ${ }^{28}$ If the interpretation of the International Law Commission is followed, human rights integration is thus mandatory as a matter of public international law. This would require at least the integrated reading of all human rights treaties concluded among the same parties (for instance all treaties ratified by all Council of Europe member states). But more likely it would go a lot further and require the integrated reading of all human rights treaties adhered to by the relevant state (or by both states parties in case of an inter-state dispute).

However, the mandate of most supranational human rights monitoring bodies extends to the monitoring of a single treaty only. For example, the European Court of Human Rights can apply directly only the European Convention on Human Rights (ECHR) and its additional protocols. The other Council of Europe human rights treaties, such as the European Social Charter, the Framework Convention for the Protection of National Minorities or the Convention on preventing and combating violence against women and domestic violence have not been brought under the Court's supervision, even though most Council of Europe member states adhere to all Council of Europe human rights treaties, and regardless of the fact that provisions of several treaties may apply to any set of facts. This is different in the Inter-American system: the Inter-American Commission and Court of Human Rights can find violations not only of the American

26 Martti Koskenniemi, 'Fragmentation of international law: difficulties arising from diversification and expansion of international law, Report of the Study Group of the International Law Commission', UN Doc A/CN.4/L.682 (2006) 208.

27 ibid, 212.

28 ibid, 238. 
Convention on Human Rights (ACHR), but also of other, more specialized treaties within the Inter-American system, such as the Inter-American torture convention, or the Inter-American convention on violence against women. The African system goes furthest along this path: the African Commission and Court on Human and Peoples' Rights can rule on the interpretation and application of all relevant Human Rights instruments ratified by the states concerned. ${ }^{29}$ As a result, references to 'external' sources abound in the case law of the African Commission and Court.

Despite their limited mandates, several supranational human rights monitoring bodies have demonstrated their sensitisation to the logic of an integrated perspective on human rights, by developing a practice of cross-references. In such practice, reference to external primary sources and/or to the outcomes or lines of reasoning of other human rights monitoring bodies, becomes part of the analysis and may serve as an argument in favour of a particular approach to the case.

The Inter-American Court of Human Rights has interpreted Article 29(b) and (d) $\mathrm{ACHR}^{30}$ as 'not only authorizing but requiring interpretation

29 Article 60 African Charter on Human and Peoples' Rights reads: 'The Commission shall draw inspiration from international law on human and peoples' rights, particularly from the provisions of various African instruments on Human and Peoples' Rights, the Charter of the United Nations, the Charter of the Organisation of African Unity, the Universal Declaration of Human Rights, other instruments adopted by the United Nations and by African countries in the field of Human and Peoples' Rights, as well as from the provisions of various instruments adopted within the Specialised Agencies of the United Nations of which the Parties to the present Charter are members.' Article 3(1), Protocol to the African Charter on Human and Peoples' Rights on the Establishment of an African Court on Human and Peoples' Rights reads: 'The jurisdiction of the Court shall extend to all cases and disputes submitted to it concerning the interpretation and application of the Charter, this Protocol and any other relevant Human Rights instrument ratified by the States concerned.'

30 Article 29 'Restrictions Regarding Interpretation' reads:

No provision of this Convention shall be interpreted as:

a. permitting any State Party, group, or person to suppress the enjoyment or exercise of the rights and freedoms recognized in this Convention or to restrict them to a greater extent than is provided for herein;

b. restricting the enjoyment or exercise of any right or freedom recognized by virtue of the laws of any State Party or by virtue of another convention to which one of the said states is a party;

c. precluding other rights or guarantees that are inherent in the human personality or derived from representative democracy as a form of government; or

d. excluding or limiting the effect that the American Declaration of the Rights and Duties of Man and other international acts of the same nature may have. 
in light of other human rights obligations, and more broadly an entire corpus juris of international human rights law' ${ }^{31}$

In the case law of the European Court of Human Rights, multiple references can be found to other sources of human rights law. Such references are recurrent and fairly extensive in the part of the judgment setting out relevant law. Yet more interestingly, they also occur in the operative part of judgments, steering the Court's interpretation of the ECHR. ${ }^{32}$ The Court has provided a double justification for this external input in its interpretation of the European Convention. First, the Court states that it 'has never considered the provisions of the Convention as the sole framework of reference for the interpretation of the rights and freedoms enshrined therein. On the contrary, it must also take into account any relevant rules and principles of international law applicable in relations between the Contracting Parties'. ${ }^{33}$ Second, the Court 'observes that it has always referred to the "living" nature of the Convention, which must be interpreted in the light of present-day conditions, and that it has taken account of evolving norms of national and international law in its interpretation of Convention provisions' ${ }^{34}$ It is to be noted that only the first of these arguments limits the range of relevant treaties to the ones adhered to by the state defendant in the case at hand. The second argument appears to be the dominant one in the Grand Chamber's reasoning, when it states that 'the common international ... law standards of European States reflect a reality that the Court cannot disregard when it is called upon to clarify the scope of a Convention provision that more conventional means of interpretation have not enabled it to establish with a sufficient degree of certainty' ${ }^{35}$ The Court specifies that 'in searching for common ground among the norms of international law it has never distinguished between sources of law according to whether or not they have been signed or ratified by the

\footnotetext{
31 Neuman, Chapter 3 in this volume; see also Verdonck and Desmet, Chapter 16 in this volume.

32 See CoE, European Court of Human Rights (ECtHR) Research Division, 'The use of Council of Europe Treaties in the Case-law of the European Court of Human Rights', June 2011 and (for a broader perspective including non-human rights related treaties) CoE, ECtHR Press Unit, 'Use of international conventions by the European Court of Human Rights', November 2012, available at the website of the European Court of Human Rights (echr.coe.int).

33 Demir and Baykara $v$ Turkey, App no 34503/97 (ECHR (GC), 12 November 2008) para 67.

34 ibid, para 68 .

35 ibid, para 76.
} 
respondent State'. ${ }^{36}$ As a result, also non-binding instruments can have this interpretative role. ${ }^{37}$

The above illustrates that each supranational human rights monitoring body is developing its own approach to external human rights sources, and hence to human rights integration. It should be clear, then, that international human rights law does not prescribe any particular method for this purpose. That is precisely what triggered the current project.

\subsection{Approach of the Present Volume}

The rewriting concept has been practiced by top scholars in jurisdictions such as Canada, ${ }^{38}$ Australia, ${ }^{39}$ the United States, ${ }^{40}$ and the United Kingdom, ${ }^{41}$ and appears to be mostly undertaken from a perspective of feminist jurisprudence. Several of these projects have opted for a common theoretical framework and a unified methodological approach. Such is deliberately not the purpose of the present volume. ${ }^{42}$

It is not the editors' intention to promote any particular view of the desirable degree or means of 'human rights integration'. Given the highly innovative character of the idea itself, human rights integration is not an issue on which many scholars have formulated or even formed definite ideas. Rather, the research project behind the book is an invitation for scholars to reflect on the issue of human rights integration in a very concrete manner. Through the rewriting approach, the purpose of the project is to identify and develop some of the multiple ways in which

\footnotetext{
36 ibid, para 78.

37 The Court in Demir and Baykara gives the example of several references to the European Union's Charter of Fundamental Rights, even though this instrument was not binding at the time: ibid, para 80 .

38 The Women's Court of Canada, Rewriting Equality, accessed 6 March 2017 at http://womenscourt.ca/.

39 Heather Douglas, Francesca Bartlett, Trish Luker, Rosemary Hunter (eds), Australian Feminist Judgments. Righting and Rewriting Law (Hart Publishing 2014).

40 Jack Balkin (ed.), What Brown v. Board of Education Should Have Said: The Nation's Top Legal Experts Rewrite America's Landmark Civil Rights Decision (New York University Press 2002); Jack Balkin (ed.), What Roe v. Wade Should Have Said: The Nation's Top Legal Experts Rewrite America's Most Controversial Decision (New York University Press 2005). See also the US Feminist Judgments Project, accessed 6 March 2017 at http://sites.temple.edu/usfeministjudgments/.

${ }_{41}$ Rosemary Hunter, Clare McGlynn, and Erika Rackley (eds), Feminist Judgments: From Theory to Practice (Hart Publishing 2010).

42 See also a previous rewriting project of one of the present editors: Eva Brems (ed.), Diversity and European Human Rights. Rewriting Judgments of the ECHR (Cambridge University Press 2012).
} 
an integrated perspective of human rights might be realized at the level of supranational monitoring bodies. Rather than promoting any single approach, the editors want to explore the range of different approaches, and the modalities of translating them into judicial practice.

It should moreover be noted that a project of human rights integration need not be a project of human rights unification. In the opinion of the editors, the exploration conducted in this volume also concerns the specific role of each supranational monitoring body within the multi-layered human rights protection system. For example, when rewriting views of the CEDAW Committee, one may be of the opinion - depending on one's view on human rights integration - that this committee should aim to provide guidance on gender-sensitive interpretations of human rights provisions, in such a manner that such interpretations may apply throughout the human rights protection system. Or when rewriting views of the African Court on Human and Peoples' Rights, one may consider not only to what extent it is desirable for this court to tap into the broad 'acquis' of human rights reasoning, but also to what extent and under which circumstances it may wish to part ways with the reasoning of other supranational bodies, in order to customize rights to African conditions. The overall idea of an integrated perspective is one in which each human rights monitoring body is conscious of being part of a broader project, and reflects upon its role in that project.

Aside from watching over the inclusion of a sufficient number of different supranational human rights monitoring bodies, the editors have left contributors free in their choice of the decision to be redrafted. Some rewrites are driven chiefly by the author's stance on what is desirable in terms of human rights integration, or more broadly in terms of good judicial practice. Others are mostly driven by the author's theoretical or conceptual view of the substantive human rights matters that are at stake in the case (with human rights integration as one of the tools supporting the argument for that view). Most chapters include a combination of both. It was agreed that contributors did not have to share the opinion that human rights integration is a good thing per se. One might for example take a stance on the benefits of mainstreaming children's rights throughout human rights law, or on integrating economic and social rights with civil and political rights to emphasize their indivisibility, without having any opinion on other types of human rights integration. The only expectation was that human rights integration would be a central feature of the rewriting exercise. In pragmatic terms, this was operationalized in terms of 'borrowing good ideas developed in one sphere or layer of human rights law and applying them in another sphere of human rights law'. The concept note of the project listed, in an open fashion, five types 
of such borrowing: (a) from a specific context (group-specific treaty or thematic treaty) to a general context and vice versa; (b) from a regional context to the universal context and vice versa; (c) intersectionality (integrating different types of group-specific rights); (d) indivisibility (integrating economic and social rights with civil and political rights); (e) borrowing from other, thematically related, fields of international law, such as international criminal law or international development law. It was, however, explicitly not expected that contributors should agree on 'how to do' intersectionality or indivisibility, amongst others. By leaving contributors the liberty of thinking of their own ways of translating their ideas into (quasi-)judicial practice, the editors aimed at harvesting a rich variety of approaches.

Some technical issues were agreed upon. The rewrite does not have an historical purpose, and therefore contributors should feel free to take into account developments posterior to the original decision. And the institutional and procedural rules of the body whose decision is being rewritten were to be respected. ${ }^{43}$ Finally, it was stated that references to domestic case law (for example, judgments of constitutional courts) could also be made, to the extent that the author was of the opinion that within the broader field of human rights law (including domestic law), particularly interesting developments were taking place in that domestic forum.

In terms of the overall style of the rewrite, most contributors have chosen to remain fairly close to the original. However, all rewrites include significantly more references to external sources than the average decision of the relevant monitoring body. Both contributors who have experience as members of the UN Human Rights Committee, pointed out that this Committee is very reticent to refer to external sources. They do so in the rewrite nevertheless, yet with more restraint than most other contributors. ${ }^{44}$ Most other authors also deliberately opted for a realistic approach, avoiding radical departures from current practice. In their chapter, Antoine Bailleux and Isabelle Hachez motivate this by stating that they want to be 'good chain novelists' in the Dworkinian sense,

43 An exception was made for the situation in which changing institutional or procedural rules, from a perspective of human rights integration, was part of the chapter's argument. However, in practice, authors who are proposing drastic institutional or procedural changes have chosen to highlight those only in the chapter, and to adopt a more 'realistic' approach in the rewrite itself. See in particular Chapter 7 by Vandenhole and Chapter 16 by Verdonck and Desmet.

44 See Chapter 3 by Neuman and Chapter 14 by Scheinin in this volume. 
making their story 'at least partly consistent with the chapters previously written by the Court'. ${ }^{45}$

At the same time, several contributors have aimed to improve the overall quality of legal reasoning of the original opinion. Indeed, in a broader sense, an integrated perspective on human rights points at a learning community of human rights monitoring bodies which strive for best practice in form as well as substance. In the words of Magnus Killander, 'a human rights integration approach should consider not only integration of substantive law but also what different courts and quasi-judicial bodies can learn from each other with regard to procedure and structure of judgments and decisions' ${ }^{46}$

The range of approaches in which this broad methodological framework has resulted, will be set out below.

\section{FIFTEEN REWRITTEN JUDGMENTS/VIEWS}

This volume presents fifteen rewritten opinions of supranational judicial or quasi-judicial human rights bodies. They deal with major contemporary issues such as conscientious objection by health service providers, intersectional discrimination of minority women, the rights of persons with disabilities, the rights of indigenous peoples against powerful economic interests, and the human rights impact of austerity measures.

Five are views of United Nations treaty bodies in the context of the quasi-judicial individual complaint procedures. These include three views of the Human Rights Committee (HRC), and one each for the Committee on the Elimination of Racial Discrimination (CERD) and the Committee on the Elimination of all forms of Discrimination Against Women (CEDAW Committee). The other ten are rulings of regional human rights bodies. The selection includes one judgment of the Inter-American Court of Human Rights (AmCt), and one judgment of the African Court on Human and Peoples' Rights (Afr Ct), in addition to one decision of the African Commission on Human and Peoples' Rights (Afr Cm). For Europe, one judgment is included of the European Court of Justice (ECJ), a body of the European Union. The main focus for Europe is on the Council of Europe system, with two decisions of the European Committee

45 For that reason they chose not to override in their rewrite the position adopted by the Grand Chamber of the ECJ with which they disagree, but rather to refine it. See Chapter 13 by Bailleux and Hachez in this volume.

46 Magnus Killander, Chapter 4 in this volume. 
Table 1.1 Rewritten opinions by jurisdiction

\begin{tabular}{|c|c|c|c|c|c|c|c|c|}
\hline \multicolumn{3}{|c|}{ Europe } & \multicolumn{2}{|c|}{ Africa } & \multirow{2}{*}{$\frac{\text { Americas }}{\mathrm{AmCt}}$} & \multicolumn{3}{|c|}{ United Nations } \\
\hline ECtHR & ECSR & ECJ & $\mathrm{Afr} C t$ & Afr Cm & & $\overline{\mathrm{HRC}}$ & CERD & CEDAW \\
\hline$R M T$ & $I P P F-E N$ & Glatzel & Zongo & $S E R A C$ & Sarayaku & $A P$ & $\begin{array}{l}\text { Yilmaz- } \\
\text { Dogan }\end{array}$ & $A S$ \\
\hline $\begin{array}{l}R M S \\
\text { McDonald } \\
C L R\end{array}$ & $I K A-E T A M$ & & & & & $\begin{array}{l}\text { Joslin } \\
\text { Paadar }\end{array}$ & & \\
\hline
\end{tabular}

Table 1.2 Rewritten opinions by date

\begin{tabular}{|c|c|c|c|c|c|c|}
\hline 1988 & 2001 & 2002 & 2006 & 2012 & 2013 & 2014 \\
\hline \multirow{4}{*}{$\begin{array}{l}\text { Yilmaz- } \\
\text { Dogan } \\
\text { (CERD) }\end{array}$} & $\begin{array}{l}\text { SERAC } \\
\quad \text { (Afr Cm) }\end{array}$ & $\begin{array}{l}\text { Joslin } \\
\quad \text { (HRC) }\end{array}$ & $\begin{array}{l}A S \\
\quad(\text { CEDAW })\end{array}$ & $\begin{array}{l}I K A-E T A M \\
\text { (ECSR) }\end{array}$ & $A P(\mathrm{HRC})$ & Paadar (HRC) \\
\hline & & & & $\begin{array}{l}\text { Sarayaku } \\
(\mathrm{AmCt})\end{array}$ & $\begin{array}{l}R M S \\
\quad(\mathrm{ECtHR})\end{array}$ & $R M T(\mathrm{ECtHR})$ \\
\hline & & & & & $\begin{array}{l}I P P F-E N \\
\quad(\mathrm{ECSR})\end{array}$ & Zongo (Afr Ct) \\
\hline & & & & & & $\begin{array}{l}\text { McDonald } \\
\quad(\text { ECtHR }) \\
\text { Glatzel }(\mathrm{ECJ}) \\
\text { CLR }(\mathrm{ECtHR})\end{array}$ \\
\hline
\end{tabular}

on Social Rights (ECSR) and four judgments of the European Court of Human Rights (ECtHR). This is shown in Table 1.1.

The large majority of the redrafts concern very recent opinions, and all but one were adopted in the 21st century (see Table 1.2). Some authors have deliberately selected a somewhat older landmark judgment, opting to reconsider the matter in the light of the development of human rights law broadly considered since the adoption of the original opinion. Yet most authors have chosen to engage with the current practice of supranational human rights bodies.

An integrated human rights perspective may affect the outcome of a case, and indeed four of the fifteen rewrites have changed a finding of 'no violation' into a finding of a violation. Yet a holistic, integrated perspective of human rights law affects in the first place the reasoning of a supranational human rights body. Hence, it does not come as a surprise that seven of the fifteen rewrites do not affect the outcome: these are five cases in which the original outcome was a finding of one or more 
Table 1.3 Rewritten opinions by outcome

\begin{tabular}{|c|c|c|c|}
\hline $\begin{array}{l}\text { No violation to } \\
\text { violation }\end{array}$ & $\begin{array}{l}\text { Violation remains } \\
\text { violation }\end{array}$ & $\begin{array}{l}\text { Negative outcome } \\
\text { remains }\end{array}$ & $\begin{array}{l}\text { Additional } \\
\text { violation(s) found }\end{array}$ \\
\hline$R M T(\mathrm{ECtHR})$ & Zongo (Afr Ct) & $\begin{array}{l}A P(\mathrm{HRC})- \\
\quad \text { inadmissible }\end{array}$ & $R M S(\mathrm{ECtHR})$ \\
\hline $\begin{array}{l}\text { McDonald } \\
\text { (ECtHR) }\end{array}$ & $\begin{array}{l}\text { Yilmaz-Dogan } \\
\quad \text { (CERD) }\end{array}$ & $\begin{array}{l}\text { Joslin }(\mathrm{HRC})-\text { no } \\
\quad \text { violation }\end{array}$ & $A S$ (CEDAW) \\
\hline Glatzel (ECJ) & $I K A-E T A M(\mathrm{ECSR})$ & & $S E R A C(\mathrm{Afr} \mathrm{Cm})$ \\
\hline Paadar (HRC) & $\begin{array}{l}I P P F-E N(\mathrm{ECSR}) \\
C L R(\mathrm{ECtHR})\end{array}$ & & Sarayaku (AmCt) \\
\hline
\end{tabular}

human rights violations, one case in which the original finding of no violation is left intact in the rewritten decision, and one case in which the original finding of inadmissibility remains unchanged. The remaining four cases concern decisions that found one or more violations, yet in which the redrafter, building on human rights integration arguments, has identified additional violations. These concern both the examination of the case and the finding of a violation under a provision that was not examined in the original decision (in $R M S,{ }^{47} S E R A C^{48}$ and Sarayaku), ${ }^{49}$ and the identification of additional violations under provisions that were already found to be violated in the original decision (in $A S, S E R A C$ and Sarayaku). The latter concern either the identification of additional state obligations that were violated,$^{50}$ or the identification of (violations of) additional rights that are not expressly protected in the reference treaty. ${ }^{51}$ See Table 1.3.

47 In this case, the redraft addresses the issue of discrimination (article 14 ECHR), which was not as such addressed in the original.

48 The redraft adds analysis under the combined articles 14 (property) and 22 (cultural identity) of the African Charter.

49 The redraft adds analysis under article 23 (right to political participation) of the American Convention.

50 See for example the addition of violations of positive obligations where the original decision only mentioned negative obligations, in $A S$.

51 See for example the identification of a right to a healthy environment in Sarayaku, as well as the newly formulated 'right to choose their own development path'. 


\section{WRITING INTEGRATED HUMAN RIGHTS: WHAT, HOW, WHY?}

\subsection{Integrating What?}

In pragmatic terms, the implementation of human rights integration is expressed in the rewritten decisions mostly in terms of the introduction of references to external sources of human rights law (including soft law), in addition to some other sources of public international law. These include both primary sources (conventions, declarations), and the output of the monitoring bodies. In Table 1.4 below, seven types of external sources are distinguished: a) (other) regional human rights conventions and/or relevant case law of the regional monitoring bodies; b) (other) United Nations human rights treaties and/or output of the UN human rights treaty bodies; c) output of the UN Charter-based human rights mechanisms; d) soft law standards at the universal level; e) soft law standards at the regional level; f) sources of other branches (not human rights) of public international law; g) domestic case law.

The table shows a strong preponderance of the first two categories. This is to be expected, as these are the strongest supranational human rights standards and decisions in legal terms, and as domestic law was not a necessary feature of the exercise.

In his chapter (Chapter 14), rewriting an HRC decision on indigenous rights, Martin Scheinin has combined the integration of an external source (the United Nations Declaration on the Rights of Indigenous Peoples) with what he has termed 'internal integration'. In casu, he has proposed what he terms a 'better integration between various provisions of the ICCPR'. Concretely, these are articles 1 (self-determination of peoples), 26 (non-discrimination) and 27 (minority rights). The integration takes place by applying the different provisions to the same facts, as well as by interpreting article 27 in light of article 1 and interpreting article 26 in light of article 27 . It is submitted that the concept of internal integration is a valuable addition to the framework of human rights integration. Indeed, the methodological stance of considering human rights law as much as possible in its entirety, does not necessarily require the mobilisation of external sources. Several human rights treaties combine civil and political rights with economic, social and cultural rights, or combine a universal approach with provisions that are tailored to specific groups. Also, most human rights treaties include a non-discrimination provision, which is a polyvalent vehicle for human rights integration. This is shown in the chapter by Scheinin as described above, as well as in the chapter by Valeska David 

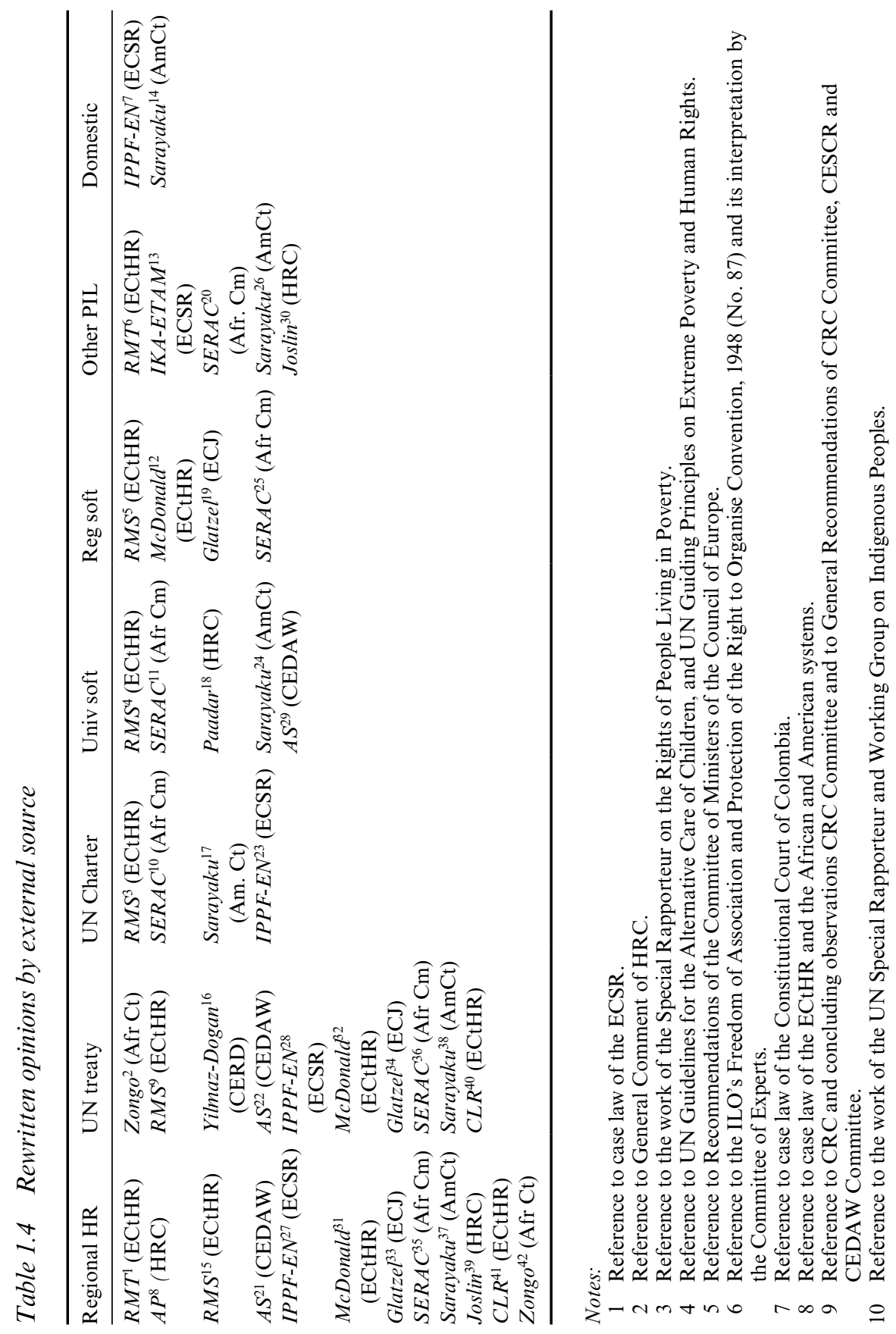


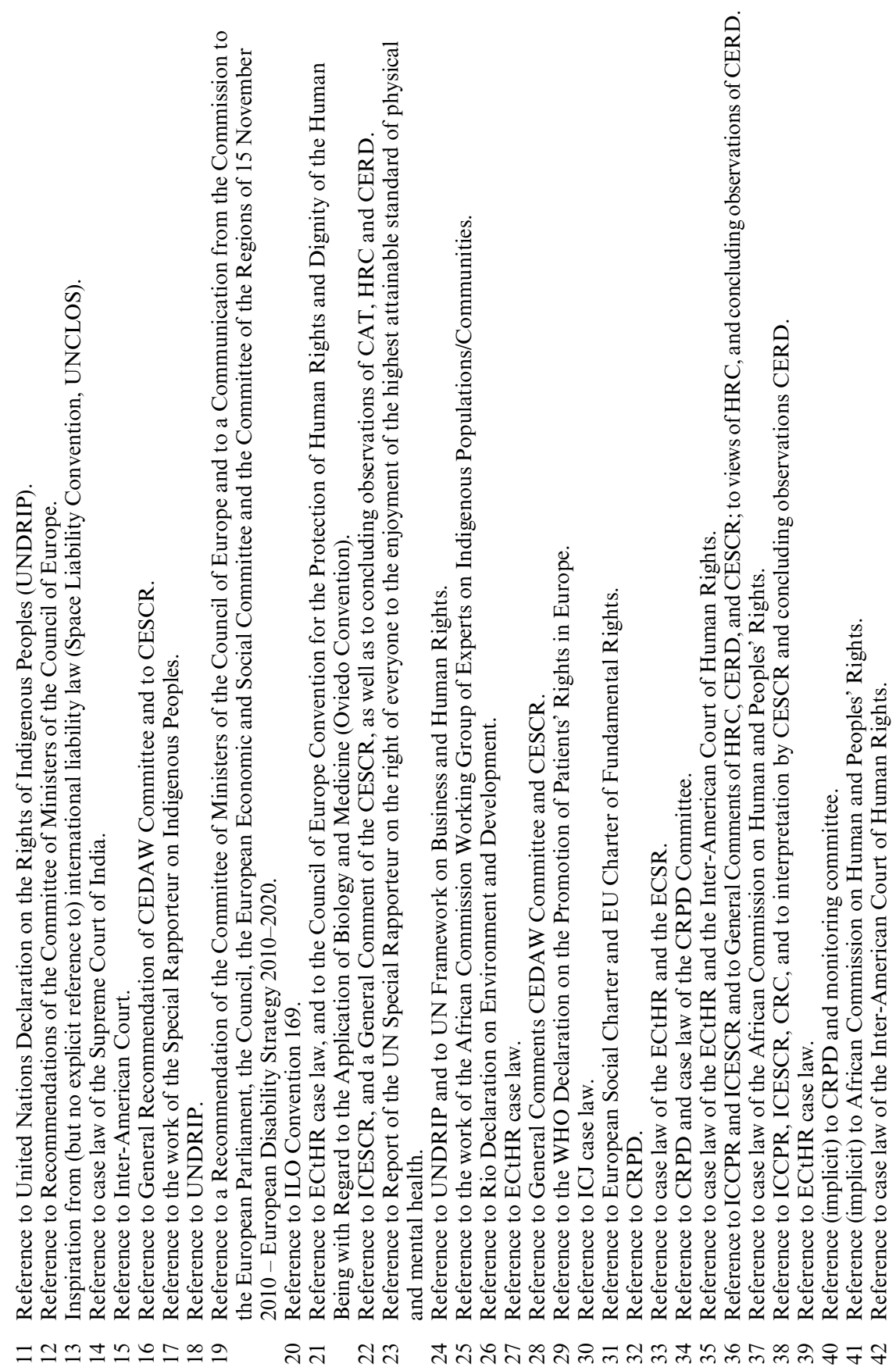


(Chapter 6) on $R M S S^{52}$ From a broader angle, all instances in which arguments under one treaty provision are modelled on existing case law under another provision of the same treaty, can be considered as arguments of internal human rights integration.

\subsection{Integrating How?}

A supranational human rights monitoring body that consciously adopts an integrated approach to human rights law, situates its own work in a broader context that includes a multi-layered universe of sources of human rights law, as well as the output of other human rights monitoring bodies. Explicit referencing of external sources in the merits reasoning is not the only way in which such an approach can be expressed. Some of the rewrites show that an integrated approach can also be implicit, or could be limited to a reference in the part of the decision that does not address the merits.

An example of implicit referencing of external sources can be found in Malcolm Langford's rewrite of the HRC's views in Joslin on samesex marriage (Chapter 5), specifically as regards so-called 'consensus' reasoning. This is a line of reasoning that conditions dynamic interpretation of human rights standards upon the prior existence of a sufficiently broad consensus on the new interpretation among states parties, as expressed primarily through domestic law. As the accompanying chapter shows, the primary reference for the rewrite was the ECtHR's approach to consensus reasoning on this same issue. However, as the rewriter ultimately rejects that approach in favour of a new one, the reference does not appear in the rewritten views.

Helena De Vylder's rewrite of the ECtHR's judgment in $C L R$ (Chapter 11 ), is the clearest example of the implicit approach. Her rewritten judgment does not include any reference to an external source. Yet the accompanying chapter reveals that the actio popularis that she proposes is modelled largely on the approach of the African Commission on Human and Peoples' Rights. In addition, references to the CRPD and its supervising committee, as well as to the Committee for the Prevention of Torture, are used in the chapter as authority to support the argument.

Gerald Neuman argues that there may be good reasons to keep arguments based on external sources a 'behind the scenes' matter, avoiding express reference (Chapter 3). He cites the concern of a universal body to avoid the appearance of regional bias, and the concern to avoid the

52 The additional mobilisation of the right to political participation in Sarayaku can also be seen as an instance of internal integration. 
appearance of criticizing another supranational human rights monitoring body, as well as a sentiment of solidarity with that other body. ${ }^{53}$

The ECtHR has the habit of listing legal sources in a separate section in each judgment before embarking upon its legal reasoning. The ECtHR already habitually quotes external human rights sources in this section of its judgments. Where rewriters have brought in additional external sources that were not mentioned in the original decision, this implies thus a modification of the 'sources' section of the judgment. ${ }^{54}$ In principle, such an acknowledgment of background sources might suffice as a 'light' expression of an integrated perspective, to the extent that it is an indicator that the Court has drawn inspiration from these sources for its reasoning. ${ }^{55}$ Yet most contributors to this volume have preferred an approach of explicit referencing.

Several authors have borrowed literal wording from external sources. ${ }^{56}$ Most cases of referencing though can be characterized as inspiration borrowing an idea rather than exact words - combined with (implicit) mobilisation of external authority. What exactly is borrowed varies strongly. It can be a substantive interpretation, such as a strict CRC norm on separating children from their parents, infusing an ECHR provision, ${ }^{57}$ or a list of positive state obligations developed by CEDAW, integrated in an ECSR decision. ${ }^{58}$ It can be a certain way of doing things, such as the organisation of standing rights, ${ }^{59}$ or the separate discussion of arguments made under separate provisions. ${ }^{60}$ Or it can be an interpretative rule, such as the standstill principle, developed by the ECSR and introduced in the ECJ,$^{61}$ or the rule of dynamic interpretation of terms, developed by the ICJ and introduced in the HRC. ${ }^{62}$

\footnotetext{
53 Gerald Neuman, p 94.

54 See in particular the rewritten McDonald judgment of the ECtHR.

55 See also De Pauw and De Hert, in this volume, insisting on the importance of drawing inspiration from external sources (in this case the CRPD) rather than simply mentioning them. The authors apply this idea (explicit mention in the 'sources' section as an indicator of external inspiration in the reasoning) with regard to the concept of 'dignity' in their rewrite of McDonald.

56 Examples include the rewrite of $A S$ (CEDAW Committee) by Eva Brems, and the rewrite of Joslin (HRC) by Malcolm Langford, regarding the textual interpretation of the right to marry, both borrowing from ECtHR case law.

57 David, p 160.

58 Bribosia, Isailovic and Rorive, p 272.

59 De Vylder, p 294.

60 Verdonck and Desmet, p 457.

61 Bailleux and Hachez, p 357.

62 Langford, p 130.
} 
An indirect way of relying on the authority of external sources, is the use of international materials as evidence of a growing consensus on a certain novel interpretation of a human rights provision..$^{63}$ The argument from consensus (of its states parties) is frequently used by the European Court of Human Rights, and occasionally also by the Human Rights Committee. The stronger such doctrine is, the more authority it can attach to external sources that have strong international support.

An important methodological question for the adoption of an integrated approach to human rights concerns consistency, and the issue of cherry-picking. Several contributors to this volume develop a principled approach to human rights integration ( $c f$. infra, 4.3), which they would like to see consistently applied. Other contributors have a more instrumental or pragmatic take on human rights integration. They are - for reasons of their own - propagating some kind of reform of the human rights protection system, or they are committed to a particular outcome in a case, and they selectively search for external authority and/or inspiration to build their argument. Some examples of this instrumental approach can be found in Helena De Vylder's argument for an actio popularis before the ECtHR (Chapter 11), and in Wouter Vandenhole's argument for joint responsibility of states and international organisations (Chapter 7). The principled and the pragmatic approach are quite different paradigms, with different consequences for the acceptability of cherry-picking. When one is engaged in a project of legal innovation, it is obviously legitimate to selectively search for sources of inspiration that can contribute to the goal one is pursuing. It is not a coincidence that in the two instances mentioned supra, the authors chose not to make explicit reference to external sources in the rewritten judgment. That makes sense, because these rewrites are not driven in the first place by human rights integration. In several chapters, there is a mix of both rationales. For example, when redrafting a decision on persons with disabilities, ${ }^{64}$ one wants to make reference to the CRPD Committee both because within the broader human rights system, this is the expert body on disability that is developing the most up-to-date standards in this field (principled reason of human rights integration), and because this is seen as helpful to reach a judgment that offers strong protection for the rights of the applicant (pragmatic reason for different agenda). The same applies to references to the UNDRIP in rulings on indigenous rights. ${ }^{65} \mathrm{In}$

63 See De Pauw and De Hert, Chapter 12 in this volume, on McDonald (ECtHR) and Langford, Chapter 5 in this volume, on Joslin (HRC).

64 See Chapter 12 by De Pauw and De Hert.

65 See the Chapter 14 by Scheinin, Chapter 15 by Smis and Inman and Chapter 16 by Verdonck and Desmet. 
such a context, a cherry-picking warning ${ }^{66}$ is relevant. When the pragmatic rationale dominates, important external sources arguing against a particular agenda may deliberately be overlooked. Such a situation would undermine the principled argument for human rights integration, and hence not be beneficial in the long run for that agenda.

\subsection{Integrating Why?}

\subsubsection{General reasons}

Among the contributors, Martin Scheinin (Chapter 14), one of the promoters of a 'World Court of Human Rights', has the longest track record in promoting an integrated perspective on human rights. He expresses this as 'the methodological position that the proper way to understand and interpret human rights requires recognition of their interdependence and even indivisibility'. ${ }^{67}$ Applying this to his rewriting of the HRC's views in Paadar, he wants to integrate several provisions of the ICCPR with each other, and with the UNDRIP. He points out that article 27 ICCPR, the provision on minority rights, is 'one of the main areas where the ICCPR has added value as compared to mainstream catalogues of human rights'. ${ }^{68}$ But he detects internal inconsistency in the HRC's General Comment on this provision. This is resonant of the view that human rights monitoring bodies are part of a global human rights network and that, for that reason, they should 'pay attention to the messages coming from the other nodes of the network', and at the same time 'send out signals that can help this network to develop and thrive'. ${ }^{69}$ In Scheinin's analysis, the HRC is falling short of the latter responsibility, and his rewrite shows how it can be done better.

This 'human rights network' reasoning is in line with the rationale for human rights integration that is advanced in my own chapter (Chapter 9), namely that 'work done in one field or forum of human rights law can in many cases also benefit other fields or fora of human rights law', and that a specialized human rights monitoring body: 'should feel free and entitled to borrow from other human rights bodies whatever is relevant for the general aspects of its work, so that it can focus as much of its resources as possible on its own distinctive work ... The work it does in that field can

66 As issued by Smith (Chapter 8) and by Van Drooghenbroeck, Krenc and Van der Noot (Chapter 2), as well as by Langford (Chapter 5).

67 Scheinin, p 384.

68 Scheinin, p 385.

69 Bailleux and Hachez, p 368. 
then in turn be borrowed by other human rights bodies when they address similar challenges. ${ }^{70}$

Underlying the above rationales is the idea that integration makes human rights stronger, by mainstreaming the strengths of each node throughout the system. In the field of social rights, this is made explicit in the 'Document on the Future of the Protection of Social Rights in Europe', a framework that receives the support of Sébastien Van Drooghenbroeck, Frédéric Krenc and Olivier Van der Noot (Chapter 2). ${ }^{71}$ In this context, integration automatically leads to levelling up of human rights protection, and cannot lead to levelling down. The plurality of legal instruments in the same sphere of rights protection 'may not result in the lowering of the level of protection provided by any one of them. Quite the contrary, it should lead to strengthening the guarantee (of social rights): in the practice of legislators and courts, the different guarantees should complement each other, strengthen one another, following an integrated approach, and the interpretation of each should be enriched by taking the other sources into account and by contributing to the emerging consensus that they point at. ${ }^{72}$

Among the contributors, Gerald Neuman (Chapter 3) and Malcolm Langford (Chapter 5) provide arguments against human rights integration as well as in favour of it. In addition to textual ('consensual') grounds, Neuman identifies moral ('suprapositive') and institutional reasons that may lead a monitoring body to favour integration or resist it in a specific case. The examples he gives concern distinctive aspects of regional regimes of human rights protection. Indeed it is clear that human rights integration does not imply uniformization. While this book is a study on the benefits and possibilities of human rights integration, it is highly relevant to also study the desirable limits of human rights integration. One such limit Neuman presents and applies in his rewriting, namely the limited persuasiveness of regional human rights interpretations for the global level, especially when there is divergence among regional interpretations. ${ }^{73}$ Malcolm Langford also discusses the limits of desirable human rights integration, pointing at the need for contextualisation as well as the value of experimentalism. ${ }^{74}$

Other authors express their scepticism about the feasibility of systematic

\footnotetext{
70 Brems, p 240.

71 Van Drooghenbroeck, Krenc and Van der Noot, p 31.

72 'Document on the Future of the Protection of Social Rights in Europe', cited in Van Drooghenbroeck, Krenc and Van der Noot, p 31.

73 Gerald Neuman, p 88.

74 Malcolm Langford, p 125.
} 
human rights integration, especially at the level of the UN treaty bodies, given the limited resources they have available. ${ }^{75}$

\subsubsection{More specific reasons}

An integrated approach allows for a multi-dimensional discussion, which can be perceived as very beneficial in complex matters. For Valeska David (Chapter 6), it allows her to infuse a judgment of the European Court of Human Rights 'with children's rights, gender and poverty perspectives on human rights law'. ${ }^{76}$ This allows a more comprehensive and contextsensitive examination of the case of an applicant suffering compounded disadvantage (based on poverty and gender) and confronted with compounded stereotypes. She argues that a case like this requires an integrated approach characterized by both intersectionality and indivisibility.

Intersectionality is also an important driver of human rights integration in several other chapters. It is probably easiest to realize by human rights monitoring bodies with a broad mandate, especially if that includes a broad anti-discrimination provision. As the rewritten judgments of the ECtHR show, such a body can simultaneously address for example poverty and gender $(R M S)$ or old age and disability (McDonald). Intersectionality is of course a topical issue for monitoring bodies that specialize in a particular group of rights holders. Such bodies inherently run the risk of essentialism, that is, of ignoring the diversity within this group of rights holders on account of an excessive focus on their shared characteristic(s). Hence it is not surprising to see one rewrite integrate gender in a CERD case, ${ }^{77}$ in addition to the CERD focus on ethnicity, while another rewrite integrates ethnicity in a CEDAW Committee case, complementing CEDAW's focus on gender. ${ }^{78}$

'Doing intersectionality' is not the only reason why rewriters have resorted to the work of monitoring bodies that specialize in a specific target group. Several authors have motivated their resorting to such sources by their desire to make the decision offer more robust protection for a single category such as women, ${ }^{79}$ or indigenous peoples. ${ }^{80}$ Another motivation is the desire for jurisprudence to be up to date with the latest developments in a specific field. ${ }^{81}$ In the field of disability rights, for

75 Rhona Smith, p 224; Martin Scheinin, p 394.

76 Valeska David, p 149.

77 Rhona Smith's rewrite of Yilmaz-Dogan, p 231.

78 Eva Brems' rewrite of $A S, \mathrm{p} 249$.

79 See the rewrite of $I P P F-E N$ by Bribosia, Isailovic and Rorive, p 270.

80 Smis and Inman, p 401.

81 See De Pauw and De Hert, p 319. 
example, the latest developments can be found in the CRPD and in the work of its monitoring committee.

Another issue highlighted by Valeska David (Chapter 6) is the need to bring in additional rights holders. In the case of an applicant whose complaint concerns losing custody over her child, the child is an obvious stakeholder whose rights merit integration in the discussion. Similarly, Lieselot Verdonck and Ellen Desmet (Chapter 16) integrate a children's rights perspective in a case about indigenous land rights, and open the door to including other affected rights holders in the case. ${ }^{82}$

Moreover, Verdonck and Desmet promote an integrated approach to duty bearers' that would integrate corporate accountability. They find support for this approach in international soft law as well as domestic case law. ${ }^{83}$ Similarly, Wouter Vandenhole (Chapter 7) proposes to extend human rights duties to international organizations. He found inspiration in international liability law. For some radical changes, he claims, human rights integration is not sufficient, and recourse to other substantive canons of international law may be required. ${ }^{84}$

Some contributors advance reasons that relate to the quality of legal reasoning, especially relating to human rights monitoring bodies with comparatively less experience. For example, Magnus Killander (Chapter 4) brings in comparative material in a judgment of the African Court on Human and Peoples' Rights, for a 'clearer understanding of the reasoning underlying the Court's judgments which improves the judgment's legitimacy' ${ }^{85}$ Also, the rewrite of $A S$, one of the early cases of the CEDAW Committee, is in part focused on filling gaps in the Committee's reasoning. Authors rewriting views of the UN treaty bodies were confronted with their 'skeletal, oracular and somewhat cryptic style', ${ }^{86}$ and have attempted to add more background and more persuasive reasoning.

Finally, the rewritten judgment of Glatzel is a special case, to the extent that it attempts to argue the direct applicability of the CRPD before the ECJ. Indeed, the European Union is a party to the CRPD. In theory, there can be no more advantageous position for integrating human rights than this direct involvement. However, the ECJ has denied any direct effect of the CRPD in EU law. Rewriting Glatzel, Antoine Bailleux and Isabelle Hachez develop a creative line of reasoning to reverse this anti-integrationist line of case law. ${ }^{87}$

82 Lieselot Verdonck and Ellen Desmet, p 473.

83 Lieselot Verdonck and Ellen Desmet, p 467.

84 Vandenhole, p 184.

85 Magnus Killander, p 114.

86 Malcolm Langford, p 119.

87 Bailleux and Hachez, p 335. 


\section{CONCLUSION: THE PROOF OF THE PUDDING}

Discussions on fragmentation and integration of international human rights law are likely to continue for some time to come. The present volume does not have the ambition to offer a comprehensive theory of human rights integration. Nor does it cover all possible variations in which an integrated approach of human rights law may be expressed in practice. Yet this collection does further our understanding of what human rights integration can mean from the perspective of a supranational human rights monitoring body. It offers a view of the range of reasons that may support an integrated approach. And it showcases a variety of concrete ways of 'doing' human rights integration: what sources to refer to, how to refer to them in the text of the ruling, and so on. It is the hope of the editors that this hands-on approach will provide a constructive input in the conversation among practitioners as well as academics, and that it will facilitate dialogue between those groups of people. 
Eva Brems - 9781786433800 Downloaded from PubFactory at 04/26/2023 02:44: ๑9PM via free access 